\title{
Effective mineral additive on the basis of wastes of petrochemical plants for a concrete structural mix
}

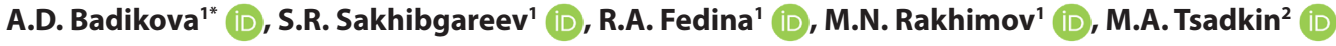 \\ 1 Ufa State Petroleum Technological University; Ufa, Republic of Bashkortostan, Russia; \\ ${ }^{2}$ Bashkir State University; Ufa, Republic of Bashkortostan, Russia. \\ *Corresponding author: e-mail: badikova_albina@mail.ru \\ (c) Authors, 2020
}

\begin{abstract}
The use of concrete in building allows obtaining reliable and long-lasting operation of buildings, but such conditions require concrete with specified characteristics. Today hardly one can produce a concrete structural mix of high quality without any additives.

To control actively the structure and properties of a concrete mix and concrete, along with chemical additives, mineral additives are used. The mineral additives are the powders of various mineral nature, obtained from natural or man-made raw materials: ground slag, rocks, etc.

The article introduces the method of obtaining a mineral additive for a structural mix, in particularly for concrete. Qualitative characteristics of the additive obtained were studied as follows: the index of the degree of grinding to be equal to 1, standard consistency

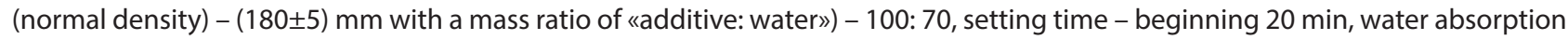
$0.27 \%$, water content $9.65 \%$, the proportion of insoluble residue in hydrochloric acid solution is $1.70 \%$.

Implementation of the additive in the concrete composition has shown that the quality of the product does not fall, and the actual strength is $250.7 \mathrm{kgf} / \mathrm{cm}^{2}$, which is slightly higher than the strength of the concrete sample without an additive. It was determined that the quality of concrete products with a mineral additive corresponds to GOST as follows: density $1775 \mathrm{~kg} / \mathrm{m}^{3}$; mass humidity $0.3 \%$; volume humidity $0.5 \%$. The introduction of a structural mix will significantly improve the properties of a concrete structural mix and will also reduce the fuel resources consumption for production of the concrete structural mix, products and constructions of its basis.
\end{abstract}

KEYWORDS: concrete structural mix, active mineral additive, sulfur-alkaline effluents of petrochemical plants, waste soda, the secondary use of materials.

FOR CITATION: Badikova A.D., Sakhibgareev S.R., Fedina R.A., Rakhimov M.N., Tsadkin M.A. Effective mineral additive on the basis of wastes of petrochemical plants for a concrete structural mix. Nanotechnologies in Construction. 2020, Vol. 12, no. 1, pp. 34-40. DOI: 10.15828/2075-8545-2020-12-1-34-40.

\section{INTRODUCTION}

$\mathrm{T}$ he majority of chemical industries is defined by considerable amount of by-products. Their utilization, on the one hand, contributes to a substantial increase in work efficiency of chemical plants and is aimed at environmental protection, on the other hand, it is a way of building materials production chemicalization, cost reduction, intensification of technological processes, line expansion and improving the quality of building products. Chemical industry of by-products can be classified by the following criteria: by the content of a specific chemical component, namely iron materials, phosphorus- and fluorine-containing slags, gypsum- and lime-containing products; by a process value in building material production, namely raw materials, intensifier of technological processes, additive-modifiers of material properties [1, 2].

For building materials production the most valuable raw materials from chemical industry by-products are slags of electrothermal production of phosphorus, lime and ferruginous waste products, polymeric products, gypsum-containing products etc. [3, 4].

In phosphorus production with a thermal method in electric furnaces, by-products are phosphorus slags. At $1300 \ldots 1500^{\circ} \mathrm{C}$ calcium phosphate interacts with coke carbon and silica, creating phosphorus and molten slag. The slag is drained from furnaces in a liquid-molten state and is granulated with a wet method. Upon obtaining $1 \mathrm{t}$ 
of phosphorus $10-12 \mathrm{t}$ of slag are formed. Up to 2 million t of slag per year can be obtained at large chemical plants. The total content of $\mathrm{CaO}$ and $\mathrm{SiO}_{2}$ is $95 \%, \mathrm{P}_{2} \mathrm{O}_{5}$ and $\mathrm{CaP}_{2}$ is $3 \%, \mathrm{Al}_{2} \mathrm{O}_{3}$ is $4 \%$ [5].

A by-product of acetylene production when water has an effect on calcium carbide is carbide residue. Lime paste on the basis of so called «carbid sludge» contains impurities of undecomposed calcium carbide and dissolved acetylene. The content of active compounds $(\mathrm{CaO}+\mathrm{MgO})$ in the carbide residue depends on its residence time in the air in dumps and is 50-60\% [6].

In sulfuric acid production by processing iron pyrite, wastes are pyritic slags (ferruginous by-products). The amount of $\mathrm{Fe}_{2} \mathrm{O}_{3}$ is $56-77 \% ; \mathrm{SiO}_{2}$ is $9-22 \% ; \mathrm{Al}_{2} \mathrm{O}_{3}$ is $1-18 \%$; $\mathrm{CaO}^{2}$ is $0.8-5.0 \%$; $\mathrm{MgO}$ is $0.1-0.2 \%$; $\mathrm{SO}_{3}$ is $1-11 \%$.

Wastes of a number of chemical industries and those related to them are gypsum-containing by-products. Gypsum-containing products are formed when manufacturing the following products: inorganic acids (phosphogypsum and phosphohemihydrate, borogypsum, ftorangidrit (hydride fluoride), fluorogypsum), organic acids (citrogypsum etc.), chemical processing of wood (hydrolytic gypsum), aqueous solutions processing of some salts and acids (silicone gypsum, titanogypsum etc.), treating of industrial gases, which contain sulfogypsum; salt production from lake brine (brine gypsum) [7].

A significant amount of raw materials containing calcium carbonate is gathered as waste within soda, pulp and paper, nitrogen and fertilizer plants. Millions of tons of fixed residue i.e. still waste sludges have gathered within soda industry plants. They are composed of the following components: $\mathrm{CaCO}_{3}$ is $50-65 \%, \mathrm{Ca}(\mathrm{OH})_{2}$ is $4-10 \%$, $\mathrm{CaSO}_{4} \cdot 2 \mathrm{H}_{2} \mathrm{O}$ is $5-10 \%, \mathrm{CaCl}_{2}$ is $5-10 \%$, impurities of clay minerals and quartz are of $5-10 \%$. One of the industrial areas of using these resources is to obtain a limebelite binder and silicate brick on its basis. The presence of calcium chloride and sulfate in wastes dramatically increases reactive capacity of raw mix, that makes it possible to kiln a binder at $950 \ldots 1000^{\circ} \mathrm{C}[8-13]$.

Wastes of soda production are also used to obtain a filler of bitumen-concrete mixes, floor covering (linoleum), a PVC tile (polyvinyl chloride) and plugging materials [14].

Sulfatcalcium wastes of hydrogen fluoride production are used as concrete and may be used when making building materials and products. This is possible due to anhydride obtained from waste by grinding and treating with sulfuric acid and its further neutralization with a calcium-containing material that excludes thermal energy consumption when obtaining the anhydride [15].

Sludge wastes on the basis of calcium carbonate are applied as cement mix from the stages of caustic treatment of sodium chloride brine to prepare a cement clinker [16, 17]. The sludge is preliminary diluted with water and gas treated on the basis of carbon dioxide followed by sludge wastes decantation and mixing of an aluminium-ferrosilicate component, which simplifies the use of sludge as a cement clinker. Sludge waste of CHP (combined heat and power station) chemical water treatment is applied as a binder in plaster and brickwork solutions. The calcium carbonate contained in sludge is proceeded to a sulfate phase by neutralizing it with a sulfuric acid solution and following it with autoclave treatment, which allows to increase binder strength and reduce water requirements [14, 18].

At the moment, a building materials industry can apply various occurring production wastes quite effectively and in large quantities to make building materials.

Products and materials of required quality are manufactured on the basis of wastes of various branches of a building materials plant, with less production costs than using virgin raw materials since costs of extraction, handling and processing of raw materials are excluded. Under current conditions, recycled raw materials are mainly used as additives, which provide building products with various properties or serve as a substitute of mineral raw materials. The building materials industry has gained positive experience in the use of wastes as raw materials to make effective building materials such as concrete, plaster and brickwork solutions, which are as good as products obtained when using virgin raw materials [19].

Due to accumulation of large quantity of various industrial wastes, today it has been a common practice to use them as mineral additives. For example, wastes of phosphorus and boron production such as phosphogypsum and borogypsum, which substitute gypsum quite effectively in concrete and building solutions, but preliminary treatment of these wastes before being used as an active mineral additive is a very time-taking and relatively inefficient process.

The content of sulfate ions in sulfur-alkaline effluents of petrochemical plants exceeds the TLV norms (threshold limit value) 72900 times for fishery objects and 72500 times for utility consumption [20]. Owing to high concentrations of sulfate ions the sulfur-alkaline effluents can be considered as an additional source of raw materials in petrochemical plants and building materials production [21].

In this paper the ways to obtain and define qualitative characteristics of a mineral additive on the basis of wastes of petrochemical and chemical industries for concrete were considered.

\section{MAIN PART}

\section{Experimental part}

Sulfur-alkaline effluents of petrochemical industries and wastes of chemical production of soda, the composition of which is shown in Table 1 and 2, were used as primary components to obtain a mineral additive. 
Table 1

Sulfur-alkaline effluents composition (waste I)

\begin{tabular}{|l|c|}
\hline \multicolumn{1}{|c|}{ Composition } & Content, $\mathbf{m g} / \mathbf{l}$ \\
\hline Sulfates & $60000-100000$ \\
\hline Sulfides & $0.001-0.500$ \\
\hline Phenols & $35-50$ \\
\hline Petroleum products & $100-200$ \\
\hline
\end{tabular}

It can be seen from the data submitted that the effluent is more saturated with sulfate ions according to the quantity of the additives contained.

The sulfur-alkaline effluent was treated with waste soda (waste II).

\section{Table 2}

Waste soda composition (waste II)

\begin{tabular}{|l|c|}
\hline \multicolumn{1}{|c|}{ Composition } & Content, \% wt \\
\hline $\mathrm{Mg}(\mathrm{OH})_{2}$ & $8-10$ \\
\hline $\mathrm{CaCO}_{3}$ & $70-80$ \\
\hline $\mathrm{CaSO}_{4}$ & $0.5-1$ \\
\hline $\mathrm{NaCl}$ & $16-20$ \\
\hline $\mathrm{Ca}(\mathrm{OH})_{2}$ & $5-8$ \\
\hline
\end{tabular}

Waste soda with various concentrations was used in the experiment, the characteristic is shown in Table 3.

\section{Table 3}

\section{Characteristic of waste II}

\begin{tabular}{|c|c|c|}
\hline No. & Concentration, $\%$ & $\boldsymbol{\rho}, \mathbf{g} / \mathbf{c m}^{\mathbf{3}}$ \\
\hline 1 & 10 & $1.011-1.012$ \\
\hline 2 & 50 & $1.050-1.051$ \\
\hline 3 & 75 & $1.081-1.082$ \\
\hline
\end{tabular}

For concrete samples preparation brand 400 portland cement was used, sand and crushed stone correspond to GOST.

For treatment of waste II with concentrations of $10,50,75 \%$, dried waste of chemical production in the amount of 100, 500, $750 \mathrm{~g}$ was used. The amount of waste, which had been preliminary determined by weighing on analytical scales, was poured in a container with a capacity of $1000 \mathrm{ml}$, further the waste was poured with water in the amount of $1000 \mathrm{ml}$. The solution was preliminary mixed before each adding.

Sulfate ions were extracted on a periodic laboratory facility. A sulfur-alkaline effluent sample under study in the amount of $200 \mathrm{ml}$ was placed into a reactor. A corresponding amount of waste soda was subsequently added drop-wise by mixing constantly. The mixing lasted for $10 \mathrm{~min}$ followed by a reaction mix to be settled for $2 \mathrm{hrs}$. The residue was divided and effluent was analyzed for the content of sulfate ions afterwards.

After preparatory drying the residue obtained was used as an active mineral additive in concrete.

Dried concrete components were weighed of definite quantities under a concrete brand (Table 4, 5), were poured on a wooden panel studded with iron and then thoroughly mixed.

\section{Table 4}

Materials consumption for preparing $1 \mathrm{~m}^{3}$ of $\mathrm{M} 200$ concrete

\begin{tabular}{|l|c|}
\hline \multicolumn{1}{|c|}{ Materials } & Content, $\boldsymbol{\%}$ wt \\
\hline ПЦ-400 concrete & 12 \\
\hline Gravel & 45 \\
\hline Sand & 30 \\
\hline Water & 13 \\
\hline Additive & 0 \\
\hline
\end{tabular}

\section{Table 5}

Materials consumption for preparing $1 \mathrm{~m}^{3}$ of $M 200$ concrete with an additive

\begin{tabular}{|l|c|}
\hline \multicolumn{1}{|c|}{ Materials } & Content, \% wt \\
\hline ПЦ-400 concrete & 9 \\
\hline Gravel & 45 \\
\hline Sand & 30 \\
\hline Water & 13 \\
\hline Additive & 3 \\
\hline
\end{tabular}

Water was added and all components were mixed afterwards until a homogeneous consistence. The amount of water used was regulated by defining concrete mix freedom of movement, which was identified by a slump cone.

The cone, which had been dipped in water beforehand was filled with a concrete mix in three layers of the same height, thus rodding each layer for 25 times using an iron core. After the concrete mix was laid in a cone, a mix excess was cut with a metal ruler and raised, ensuring that it was lifted without shifts.

Further the height of the concrete mix settled after cone removal was measured with a ruler. If the difference between cone height and concrete mix was $3 \mathrm{~cm}$ and more, the concrete mix had to be prepared again. An experiment was repeated until the normal density of the concrete mix was determined and the amount of the taken water became optimal [17, 22, 23]. 
The concrete mix was laid with a spatula in moulds with the size 10x10x10 $\mathrm{cm}$, which had been prepared in advance and oiled. 4 samples were prepared as follows: 2 standard samples of concrete and 2 samples with the addition of the mineral additive obtained. Moulds with a concrete mix were put on a vibrating table for $2-3 \mathrm{~min}$. They were compacted and evened with a spatula. Then the moulds were delivered to a steam curing room and left until the next day at temperature $\mathrm{T}=70-90^{\circ} \mathrm{C}$.

An active mineral additive was obtained from sulfuralkaline effluents on a periodic laboratory facility. The concentration of sulfate ions in an initial effluent amounted to $67600 \mathrm{mg} / \mathrm{l}$. The results are shown in Table 6 .

The content of sulfate ions in an effluent after treatment was reduced by $28532-37420 \mathrm{mg} / \mathrm{l}$. When the concentration of waste soda changes and the ratio is $1: 1$, the content of sulfate ions in a sulfur-alkaline effluent changes insignificantly.

The dependence of the content of sulfate ions in a sulfur-alkaline effluent from temperature and process time (Fig. 1, 2) was studied.

When changing process parameters the residual content of sulfate ions in waste I practically does not change.

The process material balance is calculated (Table 7).

It follows from the material balance calculated that to obtain $53.7 \mathrm{~g}$ of the residue used further as an active
Table 6

Results for sulfate ions defining

\begin{tabular}{|c|c|c|}
\hline $\begin{array}{c}\text { Waste soda, } \\
\text { aqueous } \\
\text { solution }\end{array}$ & $\begin{array}{c}\text { Ratio of «sulfur- } \\
\text { alkaline effluent: } \\
\text { waste soda» }\end{array}$ & $\begin{array}{c}\mathrm{SO}_{4}{ }^{2-} \text { concentra- } \\
\text { tion in effluent } \\
\text { after being } \\
\text { treated, } \mathrm{mg} / 1\end{array}$ \\
\hline \multirow{4}{*}{$10 \%$} & $1: 0.6$ & 58959.72 \\
\cline { 2 - 3 } & $1: 0.7$ & 39750.90 \\
\cline { 2 - 3 } & $1: 0.8$ & 36919.78 \\
\cline { 2 - 3 } & $1: 0.9$ & 36804.56 \\
\hline \multirow{4}{*}{$50 \%$} & $1: 1$ & 32261.60 \\
\cline { 2 - 3 } & $1: 0.6$ & 42300.00 \\
\cline { 2 - 3 } & $1: 0.7$ & 38220.00 \\
\cline { 2 - 3 } & $1: 0.8$ & 35340.00 \\
\hline \multirow{4}{*}{$75 \%$} & $1: 0.9$ & 34260.00 \\
\cline { 2 - 3 } & $1: 1$ & 31512.56 \\
\cline { 2 - 3 } & $1: 0.6$ & 39067.81 \\
\cline { 2 - 3 } & $1: 0.7$ & 37421.81 \\
\cline { 2 - 3 } & $1: 0.8$ & 36244.92 \\
\hline \multirow{7}{*}{5} & $1: 0.9$ & 34409.63 \\
\hline
\end{tabular}

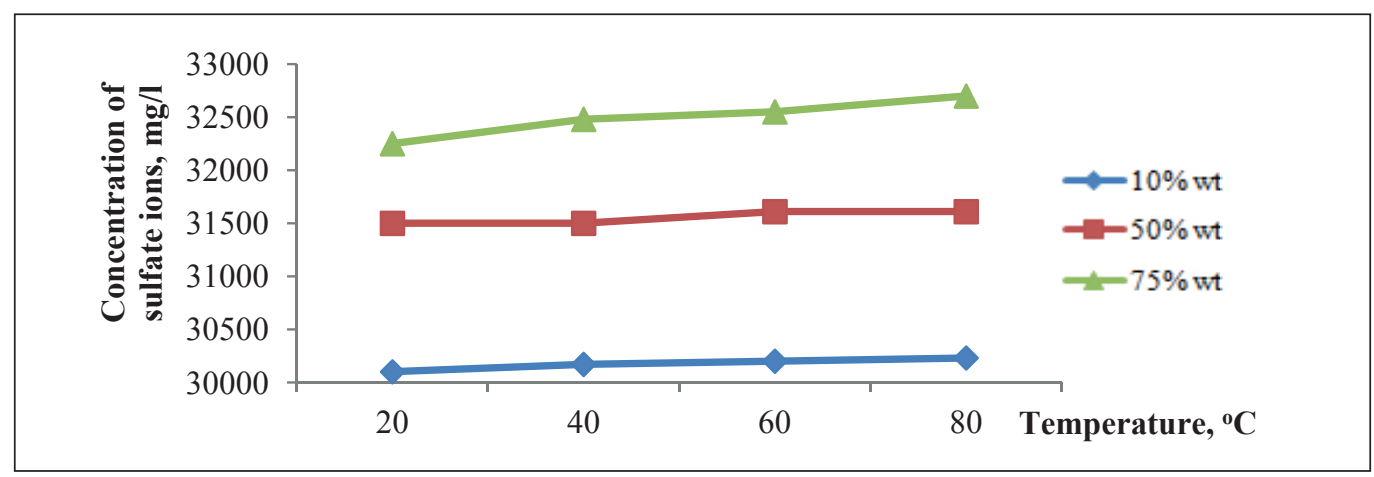

Fig. 1. Dependence of the content of sulfate ions from temperature in waste I

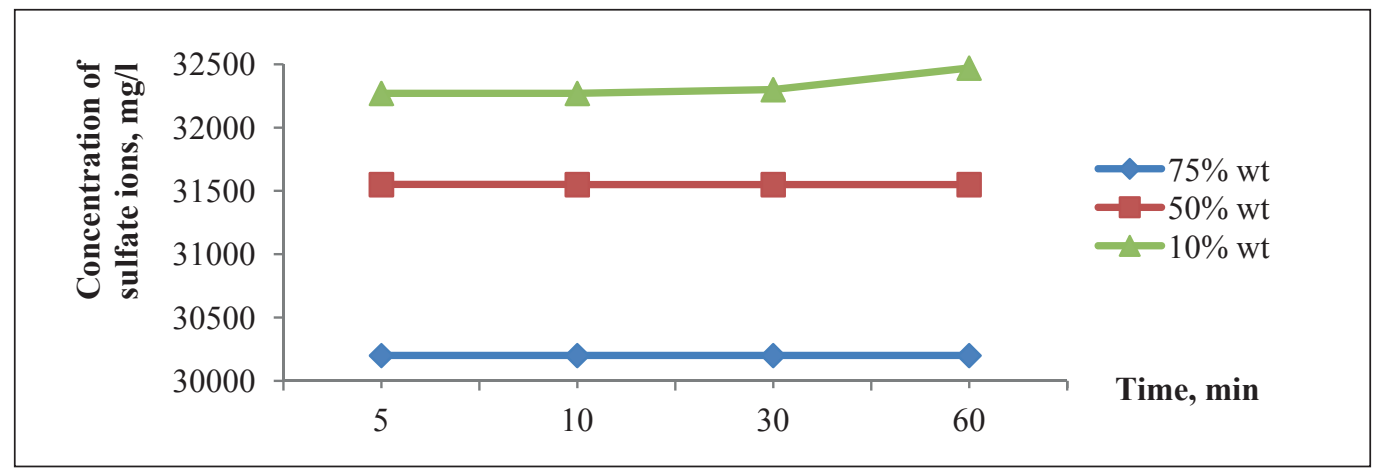

Fig. 2. Dependence of the content of sulfate ions from temperature in waste I 
Table 7

Sulfur-alkaline effluent material balance

\begin{tabular}{|l|c|c|c|c|c|}
\hline \multicolumn{1}{|c|}{ Taken } & $\mathbf{m , g}$ & $\mathbf{\%} \mathbf{w t}$ & Obtained & $\mathbf{m , g}$ & \% wt \\
\hline Sulfur-alkaline effluent & 100.00 & 50.00 & Effluent treated & 125.98 & 62.99 \\
\hline $\begin{array}{l}\text { Waste soda (75\% aqueous } \\
\text { solution) }\end{array}$ & 100.00 & 50.00 & Residue & 53.70 & 26.85 \\
\cline { 4 - 6 } & & & Loss & 20.32 & 10.16 \\
\hline & 200.00 & 100 & & 200.00 & 100 \\
\hline
\end{tabular}

\section{Table 8}

Obtaining a mineral additive from sulfur-alkaline effluents through 3 stages

\begin{tabular}{|c|c|c|c|}
\hline \multirow{4}{*}{$\begin{array}{c}\text { Waste soda, } \\
\mathbf{7 5 \%} \text { aqueous } \\
\text { solution }\end{array}$} & Stage No. & $\begin{array}{c}\text { Ratio of «sulfur-alkaline } \\
\text { effluent: waste soda» }\end{array}$ & $\begin{array}{c}\text { SO }_{\mathbf{4}}{ }^{2-} \text { concentration in effluent } \\
\text { after being treated, mg/l }\end{array}$ \\
\cline { 2 - 4 } & 1 & $1: 1$ & 30180.00 \\
\cline { 2 - 4 } & 2 & $1: 1$ & 18929.00 \\
\hline
\end{tabular}

mineral additive $100 \mathrm{~g}$ of a sulfur-alkaline effluent and $100 \mathrm{~g}$ of waste soda will be required.

Effluent multistage treatment was applied to increase residue outlet (Table 8).

In case of the sulfur-alkaline effluent being treated through 3 stages the content of sulfite ions is to be reduced by 7 times.
Based on the results acquired 3-stage treatment of the effluent is preferable to obtain greater residue outcome (Table 9)

While sulfur-alkaline effluent processing through 3 stages the residue outcome has increased to $230 \mathrm{~g}$.

The residue obtained was used an active mineral additive for concrete.

\section{Table 9}

\section{Material balance of sulfur-alkaline effluent extraction}

\begin{tabular}{|l|c|c|c|c|c|}
\hline \multicolumn{1}{|c|}{ Taken } & $\mathbf{m , g}$ & $\mathbf{\%} \mathbf{w t}$ & Obtained & $\mathbf{m , g}$ & \% wt \\
\hline Sulfur-alkaline effluent & 300.00 & 50.00 & Effluent treated & 309.50 & 51.58 \\
\hline $\begin{array}{l}\text { Waste soda (75\% aqueous } \\
\text { solution) }\end{array}$ & 300.00 & 50,00 & Residue & 230.00 & 38.33 \\
\hline & & & Loss & 60.50 & 10.08 \\
\hline & 600.00 & 100 & & 600.00 & 100 \\
\hline
\end{tabular}

Table 10

Quality parameters of the active mineral additive obtained

\begin{tabular}{|l|c|c|}
\hline \multicolumn{1}{|c|}{ Parameter } & Experimental sample & \multicolumn{1}{c|}{ Industrial sample } \\
\hline $\begin{array}{l}\text { Standard consistency, d-diameter } \\
\text { of spreading, } 180 \pm 5 \mathrm{~mm}\end{array}$ & $\begin{array}{c}\text { Mass ratio of «additive: } \\
\text { water»-100:70 }\end{array}$ & $\begin{array}{c}\text { Mass ratio of «additive: } \\
\text { water»-100:50-100 }\end{array}$ \\
\hline Setting time & Beginning 20 min - end $2 \mathrm{hrs}$ & $\begin{array}{c}\text { Beginning 20 min }- \\
\text { end is not defined }\end{array}$ \\
\hline Index of the degree of grinding & 1 & 1 \\
\hline Insoluble residue content, $\%$ & $0.5-1.7$ & $0.6-1.6$ \\
\hline Water absorption, $\%$ & 0.27 & $0.17-0.30$ \\
\hline Crystallization water content, $\%$ & 9.65 & $8.35-9.68$ \\
\hline
\end{tabular}


Table 11

Characteristic of concrete samples

\begin{tabular}{|l|c|c|c|c|}
\hline \multicolumn{2}{|c|}{ Sample notation } & \multirow{2}{*}{ Sample size, cm } & \multicolumn{2}{c|}{ Date of } \\
\cline { 4 - 5 } & & Filling & Testing \\
\hline \multirow{2}{*}{ Experimental sample* } & No. 1 & $10.06 \times 10.04 \times 10.06$ & $05 / 10 / 19$ & $05 / 11 / 19$ \\
\cline { 2 - 5 } & No. 2 & $10.06 \times 9.99 \times 10.09$ & $05 / 10 / 19$ & $06 / 08 / 19$ \\
\hline \multirow{2}{*}{ Test sample } & No. 1 & $10.09 \times 9.94 \times 10.05$ & $05 / 14 / 19$ & $05 / 15 / 19$ \\
\cline { 2 - 5 } & No. 2 & $10.10 \times 9.89 \times 10.08$ & $05 / 14 / 19$ & $06 / 12 / 19$ \\
\hline
\end{tabular}

Qualitative characteristics of the mineral additive were determined according to GOST (Table 10).

An experimental sample is slow-setting and coarse grinding. The standard consistency is under norms with a mass ratio of «additive: water»-«100:70».

Using the active mineral additive obtained samples of brand $\mathrm{M} 200 *$ concrete containing a $3 \%$ additive (Table 11) were prepared.

\section{Table 12}

\section{Concrete sample quality parameters}

\begin{tabular}{|l|c|c|}
\hline \multicolumn{1}{|c|}{ Parameter } & $\begin{array}{c}\text { Experimental } \\
\text { Sample No. 2 }\end{array}$ & $\begin{array}{c}\text { Test sample } \\
\text { No. 2 }\end{array}$ \\
\hline $\begin{array}{l}\text { Actual strength, } \\
\mathrm{kgf} / \mathrm{cm}^{2}\end{array}$ & 250.7 & 244.9 \\
\hline Density, $\mathrm{kg} / \mathrm{m}^{3}$ & 1775 & 1986 \\
\hline Mass humidity, \% & 0.3 & 0.3 \\
\hline Volume humidity, \% & 0.5 & 0.5 \\
\hline
\end{tabular}

Qualitative characteristics of the samples obtained were defined (Table 12).

When tested in concrete, the additive does not impair the quality of the product, and the actual strength is $250.7 \mathrm{kgf} / \mathrm{cm}^{2}$, which is slightly higher than the strength of the concrete sample without an additive.

\section{CONCLUSION}

Thus, the mineral additive was obtained on the basis of wastes of petrochemical and chemical plants and its qualitative characteristics were defined as follows: the index of the degree of grinding 1, standard consistency (normal density) - $(180 \pm 5) \mathrm{mm}$ with a mass ratio of «additive: water» - 100:70, setting time - beginning $20 \mathrm{~min}$, water absorption $0.27 \%$, water content $9.65 \%$, the proportion of insoluble residue in hydrochloric acid solution of $1.70 \%$.

It was shown that the quality of concrete products corresponds to GOST requirements for $\mathrm{M}-200$ brand (the actual strength of samples $250.7 \mathrm{kgf} / \mathrm{cm} 2$; density $1775 \mathrm{~kg} / \mathrm{m}^{3}$; mass humidity $0.3 \%$; volume humidity $0.5 \%$ ).

\section{REFERENCES}

1. Popov L.N. Building materials from industrial wastes. Moscow, Knowledge, 1978. pp. 55.

2. Dvorkin L.I. Building materials from industrial waste. K.: Stroyizdat, 1998. pp. 38-42.

3. Smooth K. Slags are not waste, but valuable raw materials. L.: Chemistry, Leningrad. Dep., 1989. pp. 55-57.

4. Schukina E.G., Bepple R.R. The integrated use of mineral raw materials and industrial waste for the production of building materials. Moscow, Chemistry, 2004. pp. 10-16, 20-49, 51-68, 105-116.

5. Bazhenov P.I. The use of industrial waste for the production of building materials. L.: Stroyizdat, Leningrad. Dep., 1989. pp. 12-15.

6. Vihter Ya.I. Production of lime-belite binders. Moscow, Higher School, 1974. pp. 13-15.

7. Rybev I.A. Cement-based building materials. Moscow, Chemistry, 1978. pp. 76-83.

8. Pat. 2297989 Russia, IPC C04B 11/05. A method of obtaining active anhydrite / Zykov V.M., Zykova N.S., Fedorchuk Yu.M., Tsygankova T.S. - No. 2005132129/03; declared 10/17/2005; publ. 04/27/2007. p. 3

9. Pat. 2081074 Russia, IPC C04B 7/00. The method of preparation of the raw mix to obtain cement clinker. Afanasev V.V., Kolesnikov V.Ya., Mukhanov A.A., Sukhanov M.A., Fedner L.A., Khrapov V.S., Yusupov I.G.; declared 02/13/1995; publ. 06/10/1997. p. 2. 
10. Pat. 95102840 Russia, C09K8/80. Compounds for strengthening proppant ruptures used to maintain open ruptures. Plotnikov V.A., Peychev V.G., Pribytkov E.A., Alekseev V.V.; declared 05/06/2011; publ. 10/10/2012. p. 3.

11. Pat. 2200714 Russia, C04B11/26. A method of obtaining a binder. Suchkov V.P., Kiushkin E.V.; declared 04/23/2001; publ. 03/20/2003. p. 2.

12. Smirnov D.N., Dmitriev A.S. Automatic dosing of reagents during effluent treatment and water treatment. Moscow, Chemistry, 1956. pp. 174-180.

13. Krause L.S. Preparation of solutions and concrete mixes. Moscow, Stroyizdat, 1968 . pp. 22-25.

14. Lanina T.D. Comprehensive utilization of oil and gas industrial wastes to ensure environmental safety and additional extraction of mineral raw materials. Abstract of Doctorate thesis in Engineering. Ukhta, 2009. p. 34.

15. Egorova G.I. Waste management as a social problem of improving the quality of human life. Materials of the International scientific and practical conference. Responsible author E.I. Brazhnik. -SPb.: Express, 2012. pp. 46-50.

16. Sigitova I.S. Evaluation of the effectiveness and classification of mineral additives to cements. Basic research. 2015. No. 11. pp. 1109-1113.

17. Lipunova I.N., Yupatov A.A., Alikin V.I. The use of solid industrial waste in the production of building materials. Ecology and Industry of Russia. 2009. № 3. pp. 19-23.

18. GOST 22690-2015. Concrete. Determination of strength by mechanical methods of non-destructive testing. -Introduction 04/01/2016. Moscow, Standartinform, 2016. p. 20.

19. Ivchatov A.L., Glyadenov S.N. The use of phosphorus production waste as a mineral additive in building materials. Ecology and Industry of Russia. 2007. No. 9. pp. 10-14.

20. Murtazaev S.-A.Yu., Batayev Dena K.-S., Ismailova Z.Kh. Fine-grained concrete based on fillers from recycled materials: scientific publication. Moscow, Komtekhprint, 2017. p. 142.

21. Batrakov V.G. Concrete modifiers: new opportunities and prospects. Building materials. 2006. No. 10. pp. 4-7.

22. Murtazaev S.-A.Yu, Batayev Dena K.-S., Saydumov Magomed S. Cement concrete composites on the basis of bypassed stone and stone milling wastes. Acta Technica CSAV (Ceskoslovensk Akademie Ved) 61, 2016 . No. 4B / 2016. pp. $327-336$.

23. Usherov-Marshak A.V., Babaevskaya T.V. The effectiveness of additives - the topic of concrete science and concrete technology. Technologies of concrete. 2012. No. 7-8 (72-73). pp. 53-55.

\section{INFORMATION ABOUT THE AUTHORS}

Badikova Albina Darisovna, Dr. Sci.(Eng), Professor, Ufa State Petroleum Technological University; Kosmonavtov st. 1, Ufa, Republic of Bashkortostan, Russia, 450062, e-mail: badikova_albina@mail.ru;

Sakhibgareev Samat Rifovich, post-graduate student of the 1st year of study of the Faculty of General Scientific Disciplines, Ufa State Petroleum Technological University; Kosmonavtov st. 1, Ufa, Russia, 450062, samat.sax2014@yandex.ru;

Fedina Regina Alsynovna, applicant of the Department of Physical and Organic Chemistry, Ufa State Petroleum Technological University; Kosmonavtov st. 1, Ufa, Republic of Bashkortostan, Russia, 450062, r121990@yandex.ru;

Rakhimov Marat Navruzovich, Dr. Sci.(Eng), Professor, Dean of the Faculty of Technology, Ufa State Petroleum Technological University; Kosmonavtov st. 1, Ufa, Republic of Bashkortostan, Russia, 450062, tfdekan@mail.ru;

Tsadkin Mikhail Avraamovich, Dr. Sci.(Eng), Professor, Bashkir State University; Zaki Validi st. 32, Ufa, Republic of Bashkortostan, Russia, 450076, e-mail: kuzbassufa@gmail.com.

Received: 26.12 .2019$. 